\title{
LEISHMANIA MEXICANA IN PROECHIMYS IHERINGI DENIGRATUS MOOJEN (RODENTIA, ECHIMYIDAE) IN A REGION ENDEMIC FOR AMERICAN CUTANEOUS LEISHMANIASIS 1
}

\author{
Air C. Barretto2, Norman E. Peterson², Ednaldo Lago², Ana C. Rosa2, \\ Rosely S.M. Braga ${ }^{3}$, Cesar A.C. Cuba ${ }^{2}$, Julio A. Vexenat ${ }^{2}$ and Philip D. \\ Marsden²
}

\begin{abstract}
Three isolates of Leishmania were recovered from five of 27 specimens of the rodent Proechimys iheringi denigratus Moojen captured near Três Braços in the Atlantic Forest region of Bahia, Brazil. Two of these isolates were recovered from hamsters inoculated with a pooled triturate of liver, spleen and skin tissue from apparently healthy $\mathrm{P}$. i. denigratus. The third isolate was recovered from a triturate of only skin tissue from another. Metastasis was observed in the inoculated hamsters, the parasites grew abundantly in artificial media and a typical suprapylarial pattern of infection in Lutzomyia longipalpis was produced indicating that the parasites belong to the Leishmania mexicana complex. All isolates reacted with Leishmania mexicana mexicana and Leishmania mexicana amazonensis monoclonal antibodies. The isoenzyme analysis differentiated these isolates from standard isolates of $\mathrm{L}$. m. mexicana, L. m. amazonensis, L. m. aristedesi, L. m. pifanoi, L. m. garnhami and L. m. ssp. (Goiás-W. Barbosa). These isolates seem to be a subspecies of $\mathrm{L}$. mexicana very closely related to $\mathrm{L}$. $\mathrm{m}$. amazonensis from which they differ by decreased electrophoretic mobility of GPI, PEP and ALAT.

This is the first record of the isolation of a parasite of the genus Leishmania in a rodent captured in the State of Bahia. Brazil.

Key words: Leishmania mexicana ssp. Natural reservoir. Field study. Bahia,
\end{abstract}

In Três Braços, Bahia, an area in which cutaneous leishmaniasis is endemic, the parasite most commonly isolated from skin lesions of $\operatorname{man}^{4}$ and the $\operatorname{dog} 124$ has been biologically, biochemically (isoenzymes) and immunologically (monoclonal antibodies) identified as Leishmania braziliensis braziliensis. There have been only two exceptions: one isolation of L. mexicana amazonensis (MHOM/ $\mathrm{BR} / 76 / \mathrm{LTB}-16$ ) and another of $L$. mexicana ssp. (MHOM/BR/78/LTB-55). Both were from cutaneous lesions of humans 4 .

In an attempt to find the primary reservoirs of these parasites, more than 600 wild animals, principally rodents, marsupials, rabbits and edentates, have been examined (unpublished data). This paper describes three isolates which were recovered from rodents.

1. This study was funded by the Conselho Nacional de Desenvolvimento Científico e Tecnológico (CNPq) 403690/82, US Public Health Service AI-16282, U.S. Army Medical Research and Development Command DAMD 17-84-G-4004, Ministério da Saúde (SUCAM) and the Fundaçào Serviços de Saúde Pública.

The views of the authors do not purport to reflect the position of the above named agencies.

2. Faculdade de Cièncias da Saúde, Núcleo de Medicina Tropical e Nutrição, Universidade de Brasília. DF. 70910 Brazil.

3. Unidade de Estudos Especiais, Instituto Evandro Chagas, Fundação SESP, Belém, Pará 66000 Brazil.

Recebido para publicação em 17/12/1984

\section{MATERIALS AND METHODS}

The rodents were live trapped in the tall forest habitat of the cacao growing region of Três Braços, in the municipalities of Ubaira and Wenceslau Guimarães, Bahia, Brazil. This area is located $150 \mathrm{~km}$ southwest of Salvador, latitude $13^{\circ} 32^{\prime}$ south and longitude $39^{\circ} 45^{\circ}$ west. The animals were anesthetized with chloroform and necropsied. All mammals necropsied were preserved either as skin and skull specimens or in formalin for future positive identification. Portions of skin tissue from the nose and base of tail, as well as liver and spleen, were removed for imprint smears and later triturated with saline solution and inoculated into the foot pads of hamsters. In some cases the skin and viscera were both inoculated into one hamster, in other cases the skin was inoculated into one hamster and the viscera into another. When the appearance of a cutaneous lesion indicated an inoculated hamster was harboring an infection, samples were taken for imprint smears, inoculations in new hamsters and isolation attempts in Difco blood agar culture media 13 .

Specimens of Lutzomyia longipalpis, from the colony maintained in our laboratory, were fed on the lesions and dissected following oviposition (4 or 5 days after feeding) to observe the development pattern of the parasites in the digestive tube 11 .

A battery of seven monoclonal antibodies, species and subspecies specific for the L. mexicana and $L$. braziliensis complexes, were employed to analyze the three isolates of Leishmania by indirect 
Barretto AC, Peterson NE, Lago E, Rosa AC, Braga RSM, Cuba CAC, Vexenat JA, Marsden PD. Leishmania mexicana in Proechimys iheringi denigratus Moojen (Rodentia, Echimyidae) in a region endemic for American cutaneous leishmaniasis. Revista da Sociedade Brasileira de Medicina Tropical 18: 243-246, Out-Dez, 1985

immunofluorescence ${ }^{12}$. The antibodies were from clones VI 4B9D10, XIII 3F4F6, XIII 3E6B11, XIII 2A5A10, IX 1F9D8, LXVII 1D7B8 and LXVIII 4E12D8, being one specific for L. braziliensis, three subspecific for $L$. b. braziliensis, one subspecific for $L$. mexicana amazonensis and two subspecific for $L$. $m$. mexicana. Promastigotes cultivated in Schneider's medium $^{8}$ were used as antigen. Fluorescent $\mathrm{IgG}$ antimouse conjugate (Cappel Laboratories, USA) was used at a 1:20 dilution. The isolates used as controls were MHOM/BR/83/LTB-363 (L. b. braziliensis) and $\mathrm{MHOM} / \mathrm{BR} / 75 / \mathrm{L}-3$ (Josefa) (L. m. amazonensis), both of human origin. Preliminary data have been previously reported ${ }^{3}$.

The isoenzyme analysis of the isolates, using the thin starch gel electrophoresis technique, was conducted at the Unidade de Estudos Especiais, Instituto Evandro Chagas, Belem, by R.S. Braga. The following enzymes were used: G6PD, MDH, MPI, ASAT, 6PGDH, PGM, GPI, ALAT and PEP.

\section{RESULTS}

Although none of the imprint smears of skin and visceral tissue contained amastigotes, three isolates of Leishmania (MPRO/BR/83/MTB-581/583, MPRO/ $\mathrm{BR} / 83 / \mathrm{MTB}-584 / 585$ and MPRO/BR/83/MTB574) were recovered from five of 27 specimens of the rodent Proechimys iheringi denigratus Moojen (identified by Dr. Alfred L. Gardner, National Museum of Natural History, Washington, D.C., USA). MTB-581/583 was isolated when the pooled triturate of liver and spleen tissue and skin from the nose and tail of two apparently healthy rodents was inoculated into the foot pads of a hamster. MTB$584 / 585$ was isolated in the same manner from two other animals. MTB-574 was isolated when a triturate of apparently normal skin from the nose and base of the tail of a rodent was injected into the feet of a hamster. The injection of triturate of liver and spleen tissue of this same animal into another hamster produced no apparent infection, and after a year of observation the hamster was necropsied. The skin, liver and spleen showed no parasites upon microscopic examination and culture. These results indicate that the infection with at least one of these isolates was from the skin of the rodent.

The incubation period observed in the hamsters inoculated with tissue from these Proechimys (MTB581/583, MTB-584/585 and MTB-574) varied from 2.5 to 6 months. In subsequent inoculations, this period decreased to less than 1 month. The lesions were similar to those which occur in animals inoculated with parasites of the $L$. mexicana complex with large, non-ulcerated histiocytomas rich in large amastigote forms. Metastasis to the nose, feet and testes was observed in the animals (Figure 1). but no visceralization occurred. No infection was obtained in Swiss 44 white mice inoculated intracutaneously.

The parasites grew abundantly in both media used. After an initial failure to infect Lutzomyia

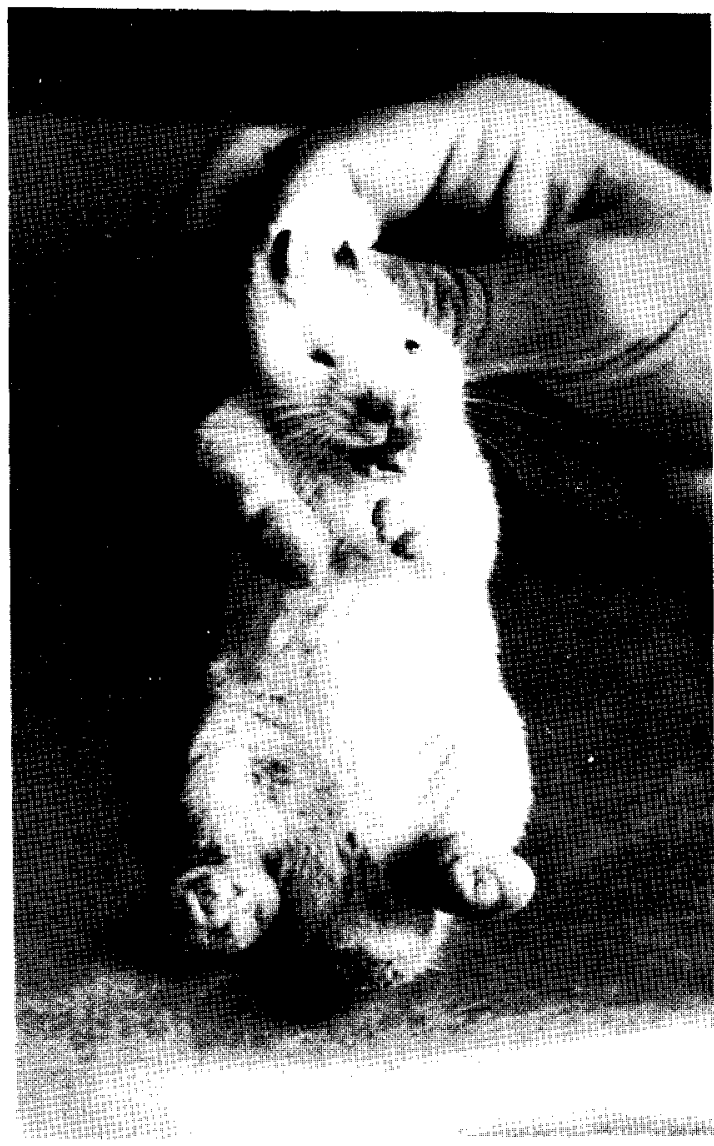

Figure 1. Hamster inoculated subcutaneousty (first passage) into the two hind feet with the strain $M P R O / B R$ $83 M T B-581 / 583$ (L. mexicana ssp.) showing lar ge non-ulcerated histiocytomas (5 months postinoculation). Positive smears and metastasis were first observed 30 days after inoculation.

longipalpis (0/30 positive), a typical suprapylaria pattern of infection was observed in $15 / 18,25 / 26$ and $12 / 17$ of this phlebotomine species with the isolates MTB-581/583, MTB-584/585 and MTB-574 respectively. None of the three isolates from the Proechimys reacted with the specific or subspecific $L$. braziliensis monoclonal antibodies. All isolates reacted with antibodies of $L . m$. amazonensis as well as $L . m$. mexicana, and could not be differentiated subspecifically. One of the $L . m$. mexicana antibodies (LXVIII 4E12D8) did not react with either the isolates from the rodents, or those of human origin, (Table 1).

The isoenzyme analysis demonstrated that the two isolates (MTB-581/583 and MTB-574) were indistinguishable from each other and differed from standard isolates of $L$. m. mexicana, L. m. amazonensis, L. $m$. aristedesi, $L$. $m$. pifanoi, $L . m$. garnhami and L. $m$. ssp. (Goias - W. Barbosa) when the following enzymes were used: G6PD, MDH, 
Barretto AC, Peterson NE, Lago E, Rosa AC, Braga RSM, Cuba CAC, Vexenat JA, Marsden PD. Leishmania mexicana in Proechimys iheringi denigratus Moojen (Rodentia, Echimyidae) in a region endemic for American cutaneous leishmaniasis. Revista da Sociedade Brasileira de Medicina Tropical 18: 243-246, Out-Dez, 1985

Table 1 - Reactivity of promastigotes of isolates of Leishmania from the rodent Proechimys iheringi denigratus from Três Braços, Bahia, Brazil to monoclonal antibodies by indirect immunofluorescence.

\begin{tabular}{|c|c|c|c|c|c|c|}
\hline \multirow[b]{2}{*}{ Clone Code (*) } & \multirow[b]{2}{*}{ Specificity } & \multicolumn{5}{|c|}{ Isolates of Leishmania } \\
\hline & & $\begin{array}{l}M P R O / B R / 83 / \\
M T B-574\end{array}$ & $\begin{array}{l}M P R O / B R / 83 / \\
M T B-581 / 3\end{array}$ & $\begin{array}{l}M P R O / B R / 83 / \\
M T B-584 / 5\end{array}$ & $\begin{array}{l}M H O M / B R / 83 / \\
L T B-363\left(^{* *}\right)\end{array}$ & $\begin{array}{l}M H O M / B R / 75 / \\
L-3\left({ }^{* * *}\right)\end{array}$ \\
\hline VI 4B9D10 & L. braziliensis & - & - & - & ++ & - \\
\hline XIII $3 F 4 F 6$ & L. b. braziliensis & - & - & - & ++ & - \\
\hline XIII 3 E6BI 1 & L. b. braziliensis & - & - & - & $++t$ & - \\
\hline XIII 2A5A10 & L. b. braziliensis & - & - & - & ++ & - \\
\hline IX 1F9D8 & L. m. amazonensis & +++ & ++ & +++ & - & $+t+$ \\
\hline LXVII 1D7B8 & L. m. mexicana & $+t+$ & ++ & +++ & - & $+t+$ \\
\hline LXVIII 4E12D8 & L. m. mexicana & - & - & - & _- & - \\
\hline
\end{tabular}

$(*)$ McMahon Pratt and David 12

(**) Control: human isolate of L. b. braziliensis

$(* * *)$ Control: human isolate of $L . m$. amazonensis (Josefa)

MPI, ASAT, 6PGDH, PGM, GPI, ALAT, and PEP. These isolates seem to be a subspecies of $L$. mexicana very closely related to $L$. m. amazonensis, from which they differ by decreased electrophoretic mobility of GPI, PEP and ALAT. Also, these two isolates differed from $L . m$. aristedesi by decreased mobility of MPI and greater mobility of ASAT.

\section{DISCUSSION}

Species of the genus Proechimys have been previously found infected with parasites of the $L$. mexicana complex. Proechimys guyannensis (Geoffroy) is considered to be the primary reservoir of $L . m$. amazonensis in the state of Pará. Brazil ${ }^{10}$, and Proechimys semispinosus (Torres), in Panama, was found to be infected with a Leishmania ${ }^{9}$ which was later designated as $L$. $m$. aristedesi ${ }^{11}$. Recently Dedet et al ${ }^{7}$ examined a new rodent species, Proechimys cuvieri Petter, from which a parasite was isolated from normal skin and identified by isoenzymes as $L . m$. amazonensis. Nine enzymes were used, and five of them (MDH, MPI, PGM, 6PGDH and GPI) coincided with those used in this study. While the GPI enzyme did not differentiate the $P$. cuvieri isolate from $L$. $m$. amazonensis, this same enzyme along with ALAT and PEP were able to separate the Leishmania isolated from the $P$. $i$. denigratus from $L . m$. amazonensis. On the other hand, Christensen et $a^{6}$ were able to distinguish electrophoretically a Panamanian strain of $L . m$. aristedesi from $L . m$. amazonensis. The former has a more rapid anodic migration for ALAT and a slower anodic mobility for malic enzyme (ME). In our laboratory we did not observe any differences between electrophoretic mobilities of two strains (MTB-574 and MTB-763/766) ${ }^{(*)}$ isolated

(*) One strain, MPRO/BR/84/MTB-763/766, was isolated after this manuscript was submitted. It is mentioned here to substantiate our original findings. from $P$. i. denigratus and two strains of $L . m$. amazonensis for malic enzyme (ME) (Figure 2) using the cellulose-acetate plate technique. The examination of a larger number of enzymes will be necessary for a better characterization of this parasite.

These isolates apparently represent the third subspecies of the $L$. mexicana complex isolated in the Très Braços region. It differs in isoenzyme characteristics and in reactivity with monoclonal antibodies from LTB-16 (L. m. amazonensis) and LTB-55 ( $L$. mexicana ssp.), both of human origin, reported earlier ${ }^{5}$. Biologically (growth in culture, inoculation in hamsters and development in the digestive tube of $\mathrm{Lu}$. longipalpis), the isolates from the rodents are
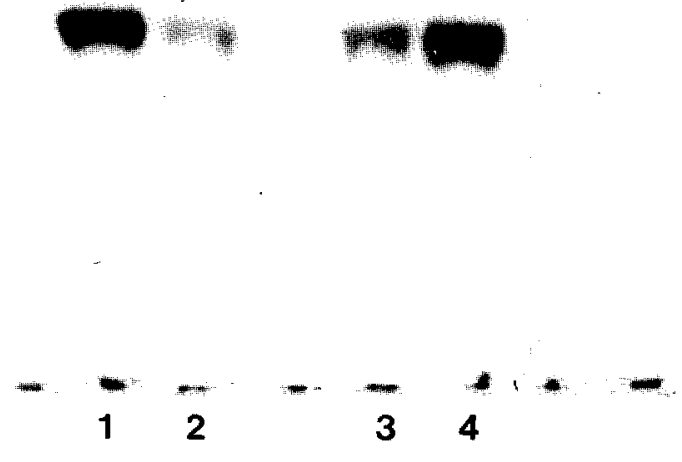

Figure 2. Cellulose-acetate plate electrophoresis showing the mobilities of the malic enzyme $(M E):(1) \mathrm{L} . \mathrm{m}$. amazonensis, 136241 , (2) L. mexicana ssp., $M P R O / B R / 83 / M T B-584 / 585$, (3) L. mexicana ssp., MPRO/BR/83/MTB-763/766, and (4) L.m. amazonensis, $M H O M / B R / 75 / L-3$ Josefa. The L. $\mathrm{m}$. amazonensis strains are used as standard references in our laboratory. 
Barretto AC, Peterson NE, Lago E, Rosa AC, Braga RSM, Cuba CAC, Vexenat JA, Marsden PD. Leishmania mexicana in Proechimys iheringi denigratus Moojen (Rodentia, Echimyidae) in a region endemic for American cutaneous leishmaniasis. Revista da Sociedade Brasileira de Medicina Tropical 18: 243-246, Out-Dez, 1985

indistinguishable from LTB-16, but differ from LTB55 which has characteristics of both $L . \mathrm{m}$. amazonensis and $L$. b. braziliensis ${ }^{5}$.

This is the first record of the isolation of a parasite of the genus Leishmania in a rodent captured in the state of Bahia. As far as we can determine, this is also the first time that a natural infection of $L$. mexicana has been reported in Proechimys iheringi denigratus.

\section{RESUMO}

Três isolados de Leishmania foram obtidos de cinco entre 27 exemplares do roedor Proechimys iheringi denigratus, capturados na região de Três Braços, na mata atlantica do Estado da Bahia, Brasil. O isolamento desse parasito foi feito atraves de inoculacào de triturado de pele, baco e figado em patas de hamsters. Em pelo menos um dos casos, (MTB-574), o parasito foi isolado da pele. Metastase foi observada nos hamsters inoculados, os parasitos cresceram abundantemente em meios artificiais de cultura e um padrào suprapapilario tipico foi obtido em Lutzomyia longipalpis, indicando que o parasito pertence ao complexo L. mexicana. Todos os isolados reagiram positivamente com anticorpos monoclonais de L. m. mexicana e L. m. amazonensis. A análise isoenzimática diferenciou $o$ parasito de isolados padróes de L. m. mexicana. L. m. amazonensis. L. m. aristedesi. L. m. pifanoi. L. m. garnhami $e$ L. m. ssp(Goiás-W. Barbosa). O parasito parece ser uma subespécie de $\mathbf{L}$. mexicana muito próxima a L. m. amazonensis, da qual difere pela menor mobilidade eletroforética de GPI, PEP $e$ ALAT.

Este é o primeiro registro do isolamento de um parasito do gènero Lcishmania em $\mathrm{um}$ roedor capturado no Estado da Bahia.

Palavras chaves: Leishmania mexicana ssp. Reservatório natural. Estudo de campo. Bahia, Brasil.

\section{REFERENCES}

1. Barretto AC, Cuba CAC, Marsden PD, Vexenat JA. Magalhães AV. Identificação de Leishmania braziliensis braziliensis em cães naturalmente infectados em uma região endêmica de leishmaniose cutâneo-mucosa. In: Resumos da IX Reunião Anual de Pesquisa Básica em Doença de Chagas (Comunicação 135) Caxambu, Minas Gerais, p. 109, 1982.
2. Barretto AC, Cuba CC, Vexenat JA, Rosa AC, Marsden PD, Magalhães AV. Caracteristicas epidemiológicas da leishmaniose tegumentar americana em uma regiào endêmica do Estado da Bahia. II Leishmaniose canina. Revista da Sociedade Brasileira de Medicina Tropical 17: 59-65. 1984.

3. Barretto AC. Peterson N. Rosa AC. Cuba C C. Vexena JA. Marsden PD. Caracterizaçāo de estoques de Leishmania isolados de cão e de roedor (Proechimis inheringi denigratus) da regiào sudeste da Bahia. atraves de anticorpos monoclonais. In: Resumos do XX Congresso da Sociedade Brasileira de Medicina Tropical. Salvador. Bahia. p. 88. 1984.

4. (uba CAC. Miles M. Vexenat A. Barker DC. Butcher J McMahon Pratt D. Barretto AC. Marsden PD. A focus of mucocutaneous teishmaniasis in Très Braços. BahiaBrazil: characterization and identification of Leishmania stocks isolated from man and dogs. Transactions of the Royal Society of Tropical Medicine and Hygiene 79: $500-507.1985$

5. Cuba CAC. Barrett) AC. Marsden PD. Leishmania mexicana: aspectos taxonomicos y rareza de la infección humana en Très Braços. Bahia. Brasil. Revista da Sociedade Brasileira de Medicina Tropical 17: 115-122. 1984.

6. Chistensen HA. Fairchild GB. Herrer A. Johnson CM. Young DG. Vasque\% AM. The ecology of cutaneous leishmaniasis in the Republic of Panama. Journal of Medical Entomology 20: 463-484.1983

7. Dedet JP. Desjeux P. Goyot P. Grosselin H. Infestation naturelle de Proechimys cuvieri Petter, 1878 (Rongeurs, Echimyides) par Leishmania mexicana amazonensis Lainson et Shaw 1972 (Kinetoplastidé, Trypanosoma (ide) en Guyane Francaise. Comptes Rendues de l'Academie des Sciences de Paris. I. 298. Serie III. No. 4: $85-87.1984$

8. Hendricks LD. Wood DE. Hajduk ME. Haemoflagellates: commercially available liquid media for rapid cultivation. Parasitology 76:309.316.1978

9. Herrer A. Telford SR. Christensen HA. Enzootic cutaneous leishmaniasis in eastern Panama. I. Investigation of the infection among forest mammals. Annals of Tropical Medicine and Parasitology 65: 349-358.1971.

10. Lainson $R$. Leishmanial parasites of mammals in relation to human disease. Symposium of the Zoological Society. London 50: 137-179. 1982

11. Lainson R. Shaw JJ. The role of animals in the epide miology of South America Leishmatriasis. In: Lumsden WHR. Evans DA (ed) Biology of the Kinetoplastida. Academic Press. London. p. 1-116.1979.

12. McMahon Pratt D. David JR. Monoclonal antibodies that distinguish between New World species of leishmania. Nature 291: 581-583,1981.

13. Walton BC. Shaw JJ, Lainson R. Observations on in vitro cultivation of Leishmania braziliensis. Journal of Parasitology 63: 1118-1119.1977. 